\title{
Malwina Popiołek
}

Uniwersytet Jagielloński

malwinapopiołek@gmail.com

ORCID: 0000-0002-9566-2773

\section{Klaudia Sroka}

Uniwersytet Jagielloński

klaudiasroka21@gmail.com

\section{BAŃKA FILTRUJĄCA IŚWIADOMOŚĆ MECHANIZMÓW JEJ FUNKCJONOWANIA WŚRÓD MŁODZIEŻY - WYNIKI BADANIA PRZEPROWADZONEGO WŚRÓD GIMNAZJALISTÓW}

\author{
Abstract \\ FILTER BUBBLE AND ITS AWARENESS AMONG YOUTH - RESULTS \\ OF A STUDY CONDUCTED AMONG JUNIOR HIGH SCHOOL STUDENTS
}

The subject of the paper is filter bubble and awareness of its mechanism among junior high school students. The article attempts to answer the question about how many representatives of the $\mathrm{Z}$ Generation (in this case junior high school students) are familiar with the issue of personalizing content on the Web, how they perceive it and whether they can manage information on the web to minimize the negative consequences of filter bubble and efficiently manage information on the Internet. 15 in-depth interviews were conducted. The results show that young people notice the effects of a filter bubble, but they do not always know the mechanisms of its. The respondents do not prevent content personalization, it is not always perceived by them negatively. People who actively create content on the Web have the best knowledge about filter bubble mechanism. The space of communication platforms such as Facebook is for a $\mathrm{Z}$ Generation natural information management environment. Social media tools are eagerly chosen, and it is often the only tool used for the information management purposes.

Key words: filter bubble, information management, content personalization, social media 


\section{Wprowadzenie}

Przedmiotem refleksji w niniejszym artykule jest kwestia indywidualnego zarządzania informacją w internecie w kontekście tzw. bańki filtrującej (ang. filter bubble) ${ }^{1}$. Zgodnie z podejściem Williama Jonesa indywidualne zarządzanie informacją (Personal Information Management $)^{2}$ odnosi się do wszelkich działań ludzkich wykonywanych w celu pozyskiwania, bieżącego organizowania, przechowywania, i wykorzystywania informacji ${ }^{3}$ niezbędnych do wykonania określonego zadania lub pełnienia jakiejś roli społecznej ${ }^{4}$. Informację należy traktować jako osobistą (indywidualną), jeżeli mieści się ona w następujących kryteriach: należy do mnie (to ja jestem jej twórcą), jest o mnie, jest do mnie skierowana, jest przeze mnie doświadczana, jest dla mnie istotna ${ }^{5}$.

Współcześnie większość naszej aktywności w środowisku internetu ma na celu zarządzanie informacją. Również obecność w serwisach społecznościowych takich jak Facebook, wbrew panującej dotychczas opinii, nie służy wyłącznie podtrzymywaniu relacji interpersonalnych czy rozrywce. Serwisy te w znacznym stopniu pozwalają nam pełnić różne role społeczne i kreować swój wizerunek ${ }^{6}$, a przede wszystkim zarządzać informacją w zakresie jej pozyskiwania czy rozpowszechniania ${ }^{7}$.

$\mathrm{W}$ artykule podjęta została próba zgłębienia zagadnień $\mathrm{z}$ obszaru indywidualnego zarządzania informacją wśród tzw. cyfrowych tubylców ${ }^{8}$. Autorki poszukiwały odpowiedzi na pytanie, czy przedstawiciele tzw. pokolenia $Z$ mają świadomość istnienia mechanizmów filtrujących treści internetowe. Na ile znane jest im zagadnienie personalizacji treści w sieci, jak je postrzegają oraz czy potrafią tak zarządzać informacją, aby minimalizować negatywne konsekwencje filter bubble i sprawnie zarządzać informacją? Problem ten wydaje się ciekawy z kilku powodów. Po pierwsze w powszechnym dyskursie częstokroć pojawiają się twierdzenia dotyczące zaawansowanych e-kompetencji wśród osób, które od urodzenia mają kontakt $\mathrm{z}$ technologiami informacyjno-komunikacyjnymi ${ }^{9}$. Zakres umiejętności niezbędnych do

${ }^{1}$ Zob. T.T. Nguyen, P.M. Hui, M. Harper, L.G. Terveen, J.A. Konstan, Exploring the Filter Bubble: The Effect of Using Recommender Systems on Content Diversity, [w:] WWW 2014 - Proceedings of the 23rd International Conference on World Wide Web, s. 677-686.

${ }^{2}$ Czasem mówi się o zarządzaniu informacją osobistą bądź też indywidualną.

3 W. Jones, Keeping Found Things Found, New York 2008, s. 5.

${ }^{4}$ W. Jones, Personal Information Management, „Annual Review of Information Science and Technology" 2007, vol. 41, nr 1, s. 453-504.

${ }^{5}$ W. Jones, dz. cyt., s. 5.

${ }^{6}$ Zob. M. Niedźwiedziński, H. Klepacz, K. Szymańska, Budowanie marki osobistej w mediach społecznościowych, „Marketing i Zarządzanie” 2018, nr 5 (48), s. 339-349.

7 Zob. M. Popiołek, Czy można żyć bez Facebooka? Rola serwisów społecznościowych w sieciowym społeczeństwie informacyjnym, Kraków 2018; B. Malinowski, Jak Facebook zamyka nas w bańce informacyjnej. Algorytm filtrujący newsfeed a zjawisko filter bubble, „Zarządzanie Mediami” 2006, t. 4(1), s. 15-22.

${ }^{8}$ Zob. M. Prensky, Digital Natives, Digital Immigrants, „On the Horizon” 2001, vol. 9, nr 5.

9 Zob. tamże. 
efektywnego zarządzania informacją $\mathrm{w}$ internecie stale ulega jednak poszerzaniu. Wymaga to zatem ciągłego przystosowywania się do nowych warunków. Aktualizacja badań w tym zakresie jest więc konieczna. Inną kwestią jest niewielka liczba źródeł polskojęzycznych. Większość badań prowadzonych w obszarze zarządzania informacją ma charakter ilościowy. Pozwalają one odpowiedzieć na pytania dotyczące poszczególnych e-umiejętności w określonych populacjach badanych, jednak nie dają odpowiedzi na pytanie, dlaczego określone kompetencje występują bądź nie.

\section{Tło teoretyczne}

Termin filter bubble został wprowadzony do dyskursu przez Eliego Parisera. Na język polski tłumaczony bywa dwojako, jako bańka informacyjna lub bańka filtrująca. Należy zauważyć, że zamienne traktowanie tych pojęć jest niewłaściwe. Bańka informacyjna jest pojęciem szerszym, wskazującym na ograniczony dostęp jednostki do zróżnicowanej informacji. Z kolei z bańką filtrującą mamy do czynienia wtedy, gdy algorytm filtrujący treści internetowe podsuwa użytkownikowi zestaw informacji wyselekcjonowanych i spersonalizowanych na podstawie danych dotyczących lokalizacji lub wcześniejszych wyszukiwań, ograniczając w ten sposób ich dywersyfikację ${ }^{10}$. Bańka filtrująca rozpatrywana jest głównie w kontekście mechanizmów działania wyszukiwarki Google oraz algorytmów zarządzających strumieniem spersonalizowanych informacji $\mathrm{w}$ serwisie Facebook ${ }^{11}$ (tak też konceptualizuje ją Pariser) i jest zjawiskiem, które pojawiło się wraz z rozwojem nowych mediów. Bańka informacyjna może być zatem konsekwencją bańki filtrującej, jednakże można mówić o niej także w oderwaniu od technologii informacyjno-komunikacyjnych, chociażby przy okazji różnych zjawisk będących konsekwencją usieciowienia relacji społecznych (np. w związku z preferencją do zawierania znajomości z osobami o poglądach i upodobaniach takich jak nasze) ${ }^{12}$.

Bańka filtrująca rozpatrywana jest zarówno w pozytywnym, jak i negatywnym kontekście. Sam mechanizm został wprowadzony przez firmy dostarczające usługi w przestrzeni informacyjno-komunikacyjnej w celu personalizacji treści, a więc lepszego dopasowania wyników wyszukiwania do potrzeb odbiorców. Algorytmy filtrujące pozwalają zatem na efektywne zarządzanie informacją. Dzięki nim koszt dotarcia do pożądanej informacji jest niższy (docieramy do niej szybciej i sprawniej). Dodatkowo serwisy takie jak Facebook zdejmują z użytkownika konieczność podejmowania jakiejkolwiek aktywności w tym zakresie. Mamy bowiem do

${ }_{10}$ Zob. Ł. Iwasiński, Przyczynek do rozważań nad suwerennością konsumenta w epoce danetyzacji i Big Data, „Kultura - Historia - Globalizacja” 2017, nr 21, s. 119-133.

11 Zob. Z. Bauman, D. Lyon, Płynna inwigilacja. Rozmowy, Kraków 2013, s. 173-174.

12 Zob. szerzej: N.A. Christakis, J.H. Fowler, W sieci. Jak sieci społeczne ksztattuja nasze życie, Sopot 2011. 
czynienia $\mathrm{z}$ biernym zarządzaniem informacją - na podstawie dotychczasowej aktywności użytkownika w sieci na tzw. tablicy pojawia się strumień spersonalizowanych treści. Ma to jednak także negatywne konsekwencje, jak bowiem trafnie zauważa Magdalena Szpunar:

Dla zrozumienia mechanizmu funkcjonowania Pariserowskiej bańki kluczowe są trzy elementy. Pierwszy z nich ma znaczenie nadrzędne. Mówi on bowiem o tym, iż w bańce (...) znajdujemy się sami; nawet wtedy, gdy istnieje grono osób o podobnych do naszych zainteresowaniach, to nie otrzymują one tożsamego z naszym zestawu treści. Drugą immanentną właściwością bańki (...) jest jej transparentność, co oznacza, że najczęściej w ogóle nie zauważamy jej istnienia. Z tej własności wynika trzecia jej cecha, a mianowicie znalezienie się w niej odbywa się poza naszą wolą ${ }^{13}$.

Z punktu widzenia rozważań dotyczących bańki filtrującej istotne jest przede wszystkim to, że nie każdy internauta ma świadomość istnienia bańki, a brak takiej wiedzy skutkuje zamknięciem w dość hermetycznej przestrzeni obiegu informacji, co z punktu widzenia funkcjonowania społeczeństwa informacyjnego jest niepożądane. Dodatkowo także użytkownicy mediów często nie mają świadomości, że platformy świadczące usługi nie są neutralne politycznie. Jak pisze M. Nowina-Konopka: „Fakt, że główne koncerny medialne są reprezentantami jakiejś opcji politycznej, jest oczywisty dla analityków mediów, ale nie dla przeciętnego internauty"14.

Personalizacja dotyczy także treści reklamowych ${ }^{15}$, co również postrzegane bywa dwojako. $Z$ jednej strony właściwie dopasowana reklama jest często doceniana i akceptowana przez konsumenta, $\mathrm{z}$ drugiej zaś zasady zbierania i przetwarzania danych służących profilowaniu nie zawsze są jasne i przejrzyste dla użytkowników, w większości przypadków nie mają oni nawet świadomości tego, jakie dane udostępniają podczas codziennego korzystania $\mathrm{z}$ urządzeń podłączonych do internetu ${ }^{16}$.

$\mathrm{W}$ przedstawionym w niniejszym tekście badaniu uczestniczyli gimnazjaliści, których uważa się za pokolenie tzw. cyfrowych tubylców. Termin ten pojawił się w związku z publikacjami Marka Prensky’ego, który postawił tezę, że młode pokolenie ludzi oswojonych $\mathrm{z}$ obecnością technologii informacyjno-komunikacyjnych (ICT) jest znacznie bardziej biegłe $\mathrm{w}$ ich obsłudze, aniżeli ludzie pamiętający czasy bez nowych mediów ${ }^{17}$. Współcześnie teoria dotycząca cyfrowych tubylców uległa znacznemu rozszerzeniu, a w ramach tej grupy wyróżniono liczne podgrupy. Badacze wyróżniają współcześnie m.in. tzw. pokolenie $\mathrm{Y}$ - osoby urodzone w latach 80. XX wieku, które dobrze znają środowisko internetu; pokolenie Z, czyli osoby

${ }_{13}$ M. Szpunar, Koncepcja bańki filtrującej a hipernarcyzm nowych mediów, „Zeszyty Prasoznawcze" 2018, t. 61, nr 2(234), s. 191-200.

${ }_{14}$ M. Nowina-Konopka, Infomorfoza. Zarządzanie informacją w nowych mediach, Kraków 2017, s. 155.

${ }^{15}$ J. Kreft, Za fasada społeczności, Kraków 2015, s. 98.

${ }_{16}$ G. Ptaszek, Edukacja medialna 3.0. Krytyczne rozumienie mediów cyfrowych w dobie Big Data i algorytmizacji, Kraków 2019, s. 209-212.

${ }_{17}$ M. Prensky, dz. cyt. 
urodzone po 1995 roku, które nie pamiętają czasów bez ICT $^{18}$; a także pokolenie Alfa, czyli osoby urodzone po 2010 roku, które dorastają, korzystając z urządzeń mobilnych ${ }^{19}$. Według tej typologii gimnazjalistów uczestniczących w badaniu należy uznać za przedstawicieli pokolenia $Z$.

Pokolenie to charakteryzuje przede wszystkim duża swoboda korzystania z różnych platform komunikacyjnych. Są to także osoby chętnie i aktywnie tworzące treści internetowe. Jak czytamy: „Wykazują się wysokim poziomem cyfryzacji i genetycznie uwarunkowaną biegłością w korzystaniu z dobrodziejstw internetu. Taka postawa powoduje $\mathrm{u}$ ich rodziców (...), w mniejszym lub większym stopniu, poczucie cyfrowego wykluczenia (...)"20. Charakterystyka pokolenia Z sugeruje, że badani gimnazjaliści powinni mieć wiedzę na temat bańki filtrującej, a także wykazywać dużą biegłość w zakresie zarządzania informacją w internecie.

\section{Metodologia}

W okresie od stycznia do kwietnia 2016 roku zostało przeprowadzone badanie jakościowe. Uczestniczyli w nim gimnazjaliści, osoby urodzone pomiędzy rokiem 2001 a 2002. Wszyscy badani aktywnie korzystali z Facebooka w momencie badania. Wybrana grupa osób została dobrana w oparciu o zasadę dostępności. Zastosowano technikę indywidualnego wywiadu pogłębionego, częściowo ustrukturyzowanego. Przeprowadzonych zostało łącznie 15 wywiadów, 8 z dziewczętami i 7 z chłopcami.

Spośród przeprowadzonych wywiadów trzy pierwsze należy potraktować jako pilotaż, który pozwolił ustrukturyzować narzędzie badawcze. Wywiady były rejestrowane, dokonano także ich transkrypcji. Jedna z rozmów na prośbę badanych dziewcząt odbyła się z obiema respondentkami. Rozmowy koncentrowały się wokół trzech wątków głównych: zarządzania informacją w codziennej aktywności on -line, efektów działania bańki informacyjnej, a także udostępniania informacji prywatnej w środowisku internetu.

W niniejszym artykule zaprezentowane zostaną wątki dotyczące bańki informacyjnej i indywidualnego zarządzania informacją w środowisku internetu. Część poświęcona udostępnianiu informacji prywatnych jest zbyt obszerna i stanowi zasadniczo inny problem, została więc opublikowana w formie odrębnego artykułu. Poniższe badanie nie było przeprowadzone na grupie reprezentatywnej, dlatego też jego wyniki nie określają umiejętności i wiedzy wszystkich gimnazjalistów. Stanowią natomiast pewien punkt wyjścia, a także wskazówkę co do kierunku ewentualnych dalszych badań.

${ }^{18}$ N. Lechowicz, D. Pikuła, Determinanty kształtujace nowe pokolenia oraz ich implikacje dla współczesnego świata, „Rynek, Społeczeństwo, Kultura” 2013, nr 3(7), s. 17.

19 G.D. Stunża, Wyzwania kultury i edukacji uczestnictwa. Pokolenie Z i pokolenie Alfa, Gdańsk 2018, s. 24.

${ }^{20}$ N. Lechowicz, D. Pikuła, dz. cyt., s. 20. 
Tabela 1. Charakterystyka próby badawczej

\begin{tabular}{|l|c|c|c|c|c|c|c|c|}
\hline \multicolumn{1}{|c|}{ Imię: } & $\begin{array}{c}\text { Wero- } \\
\text { nika }\end{array}$ & Michał & Magda & $\begin{array}{c}\text { Agnie- } \\
\text { szka }\end{array}$ & Patryk & Iwona & Partycja & Sylwia \\
\hline $\begin{array}{l}\text { Rok } \\
\text { urodzenia: }\end{array}$ & 2001 & 2001 & 2001 & 2002 & 2001 & 2001 & 2002 & 2001 \\
\hline Płeć: & kobieta & $\begin{array}{c}\text { mężczy- } \\
\text { zna }\end{array}$ & kobieta & kobieta & $\begin{array}{c}\text { mężczy- } \\
\text { zna }\end{array}$ & kobieta & kobieta & kobieta \\
\hline $\begin{array}{l}\text { Miejsce } \\
\text { zamieszkania: }\end{array}$ & wieś & wieś & wieś & wieś & wieś & $\begin{array}{c}\text { małe } \\
\text { miasto }\end{array}$ & $\begin{array}{c}\text { duże } \\
\text { miasto }\end{array}$ & $\begin{array}{c}\text { małe } \\
\text { miasto }\end{array}$ \\
\hline
\end{tabular}

\begin{tabular}{|l|c|c|c|c|c|c|c|}
\hline \multicolumn{1}{|c|}{ Imię: } & Maciek & Jan & Marcin & Ewa & Natalia & Oskar 1 & Oskar 2 \\
\hline $\begin{array}{l}\text { Rok } \\
\text { urodzenia: }\end{array}$ & 2001 & 2002 & 2002 & 2002 & 2001 & 2001 & 2002 \\
\hline Płeć: & $\begin{array}{c}\text { mężczy- } \\
\text { zna }\end{array}$ & $\begin{array}{c}\text { mężczy- } \\
\text { zna }\end{array}$ & $\begin{array}{c}\text { mężczy- } \\
\text { zna }\end{array}$ & kobieta & kobieta & $\begin{array}{c}\text { mężczy- } \\
\text { zna }\end{array}$ & $\begin{array}{c}\text { mężczy- } \\
\text { zna }\end{array}$ \\
\hline $\begin{array}{l}\text { Miejsce } \\
\text { zamieszkania: }\end{array}$ & $\begin{array}{c}\text { małe } \\
\text { miasto }\end{array}$ & wieś & wieś & $\begin{array}{c}\text { duże } \\
\text { miasto }\end{array}$ & $\begin{array}{c}\text { małe } \\
\text { miasto }\end{array}$ & wieś & $\begin{array}{c}\text { duże } \\
\text { miasto }\end{array}$ \\
\hline
\end{tabular}

Źródło: opracowanie własne.

\section{Zarządzanie informacją w środowisku internetu - wyniki badania przeprowadzonego wśród gimnazjalistów}

\section{1. Świadomość bycia w bańce informacyjnej i indywidualne zarządzanie informacją}

Biorąc pod uwagę możliwość, że terminologia dotycząca bańki filtrującej, jak również samo zjawisko personalizacji treści, mogą nie być respondentom znane, w badaniu skupiono się na tym, czy gimnazjaliści zauważają efekty działania mechanizmów filtrujących treści. Osoby biorące udział w badaniu w swoich wypowiedziach, często nieświadomie, określały najważniejsze symptomy istnienia bańki informacyjnej. Pytania dotyczące personalizacji treści koncentrowały się wokół aktywności badanych w ramach serwisu Facebook, ponieważ jak wynika z dotychczasowych badań, jest on głównym źródłem informacji dla młodych internautów ${ }^{21}$. Na wstępie, podczas wywiadu dokonano oceny, czy rozmówcy faktycznie znajdują się w bańkach filtrujących. Badane osoby określiły, jakie informacje najczęściej pojawiają się na ich tablicy w serwisie Facebook. Wywiad potwierdził wstępne przypuszczenia. Każdy z rozmówców doświadczał działania mechanizmów filtrujących, będąc w bańce, która w przeważającej części odzwierciedla jego zainteresowania, tworząc (w oparciu o aktywność w sieci i polubienia) spersonalizowany strumień informacji.

${ }^{21}$ Zob. M. Popiołek, dz. cyt.; B. Malinowski, dz. cyt. 
Co ciekawe, większość badanych osób nie była świadoma faktu, że mogą znajdować się w informacyjnym „bąblu”. Warto podkreślić, że osoby badane doceniały fakt, iż dostarczane są im informacje, które mogą ich potencjalnie zainteresować, i nie postrzegały tego zabiegu w negatywny sposób. Jak zaznaczyły, sami wybierają strony, które potem wyświetlają się na ich tablicy głównej na Facebooku. Część z nich zauważyła przy tym prawidłowość, polegającą na wyświetlaniu się częściej postów stron, z którymi wchodzą w interakcję. Może ona polegać na każdorazowym lubieniu postów, komentowaniu bądź zaznaczaniu opcji „obserwuj”. Jedna z osób zwróciła uwagę na tę prawidłowość:

(...) pewnie pokazuje nam się to, co najbardziej popularne, albo coś, co najczęściej przeglądamy. Jak na jakąś stronę częściej wchodzimy, to ona nam się wyświetla częściej niż ta, na którą wchodzimy rzadziej. [Weronika]

Wypowiedź Weroniki sugeruje, że nie ma ona pewności co do swoich słów, jednak wyciąga wnioski na podstawie obserwacji. Przyznała, że wcześniej nie poddawała refleksji wymienionych prawidłowości, natomiast udział w badaniu sprawił, że zaczęła się zastanawiać nad tą kwestią. Specyfika serwisu społecznościowego pozwala na wybór określonych stron oraz znajomych, których posty dany użytkownik chce widzieć. Słowa Weroniki trafnie oddają sposób funkcjonowania użytkownika w serwisie społecznościowym. Obecnie, przy bardzo dużej liczbie polubionych stron, Facebook generuje użytkownikowi treści, z którymi wchodził w interakcje. Równocześnie istnieje prawdopodobieństwo, że informacje, które mogą zainteresować użytkownika, nie docierają do niego.

Gimnazjaliści zapytani zostali także o to, czy znaleźli się kiedyś w sytuacji, w której ich znajomi rozmawiali na temat jakichś treści (np. o filmie, śmiesznym zdjęciu itp.), przy czym pytany nie miał pojęcia, o czym mówią. Ze wszystkich osób biorących udział w badaniu tylko jedna zaprzeczyła. Pozostali gimnazjaliści, opisując tego typu sytuacje, zaznaczali, że zdarzają się one często. Wiedza osób biorących udział w badaniu na temat powodów takiego zjawiska jest zróżnicowana. Część osób nie potrafiła wytłumaczyć takiej sytuacji, część jako powód wskazywała nadmiar informacji, natomiast kilka osób posiadało większą wiedzę w tym zakresie:

Miałem nieraz tak. Często jest tak, że niektórym na FB się wyświetli post, a mi nie. Facebook teraz bardzo ogranicza te zasięgi i żeby coś się rozeszło, to trzeba FB zapłacić. No i często jest tak, że nie dochodzi informacja do każdego, nawet mimo tego, że się lajkuje tą stronę. Tak samo jest na YouTubie. Dużo twórców się subskrybuje, a i tak połowa filmików nie pokazuje się nam w powiadomieniach. Bo oba te portale ograniczają te zasięgi. (...) Ale też miałem taką sytuację, że ja widziałem coś z paroma kolegami, ale inny kolega nie widział tego filmiku, obrazka czy tam czegoś. [Michał]

Michał jest z jedną z niewielu osób, które zauważyły mechanizmy działania serwisu Facebook, a nawet zwrócił uwagę na podobne działania innego serwisu - YouTube. Jego wiedza opiera się na własnych doświadczeniach, ponieważ jak wspomniał, posiada własny kanał, na którym publikuje treści. Dzięki temu jest 
on bardziej świadomy mechanizmów, jakie wprowadzają serwisy społecznościowe. Potwierdza to hipotezę, którą stawiali Alexander Bard i Jan Soderqvist, twierdzący, że największą grupą beneficjentów internetu będą użytkownicy aktywnie tworzący treści ${ }^{22}$. Michał jest osobą, której wiedza i działania potwierdzają tę teorię. Jednym z przejawów znajdowania się w bańce informacyjnej jest także wspomniana wcześniej możliwość, że nie wszystkie informacje docierają do użytkownika. Dwie osoby uczestniczące w badaniu zwróciły uwagę na sytuację, w której odkryły, że pewne informacje nie dotarły do nich, chociaż obserwowały stronę, która daną treść udostępniła:

Właśnie czasami sprawdzam jakąś konkretną stronę i się okazuje, że jest dużo informacji które mi się nie pokazały. (...) Jest taki youtuber z Australii i jak coś robił, to wtedy żałowałam, że tego nie widziałam. [Magda]

Wskazywano także na inny przejaw bańki filtrującej:

Jak na przykład czegoś szukam w Google, to czasami nie wychodzi mi to, czego szukam, tylko coś podobnego dostaję, ale nie to, o co mi chodziło. Więc trzeba pisać bardzo dokładnie, żeby się wyszukało. [Weronika]

Weronika odwołuje się do sytuacji, w której pomimo wpisania odpowiedniej frazy do wyszukiwarki nie dostaje wyniku, który zawierałby potrzebne jej informacje. Powodem takiej sytuacji może być próba dopasowywania wyników do zainteresowań użytkownika na podstawie jego wcześniejszych wyszukiwań.

Istotnym aspektem, który może świadczyć o tym, że użytkownicy nie są w pełni świadomi, że część informacji do nich nie dociera, jest fakt, że nie potrafią oni określić precyzyjnie liczby polubionych w serwisie społecznościowym stron. Liczby wymieniane przez uczestników badania wahały się w granicach 30, 100 a nawet 500 obserwowanych stron. Odpowiadając na pytanie o tę kwestię, część gimnazjalistów uświadomiła sobie, że nie ma możliwości, by byli w stanie przeczytać i zobaczyć wszystkie treści, które te strony publikują. Algorytm sprawia, że na ich tablicach pojawia się tylko część polubionych stron, co dodatkowo potęguje efekt bańki.

Wśród osób badanych były także takie, które w pewien sposób zarządzają treścią, która do nich dociera. Jednym z przykładów jest zaprzestanie obserwowania danej strony, jeżeli treść przez nią publikowana już ich nie interesuje:

Jak nie czytam [informacji], to „odlubiam” taką stronę, żeby nie zajmowało mi to miejsca. [Agnieszka]

Czasami te strony były zrobione, ale już nie działają, a Facebook to selekcjonuje na podstawie tego, czy my to widzimy albo reagujemy (...) Jeżeli te strony już nie działają, to je „odlajkowywuje”. [Patryk]

${ }^{22}$ A. Bard, J. Soderqvist, Netokracja. Nowa elita władzy i życie po kapitalizmie, Warszawa 2006, s. 260 . 
Powyższe wypowiedzi świadczą o próbie indywidualnego zarządzania informacją w zakresie jej pozyskiwania. Oprócz tego wiele osób przyznało, że zdarza się im usuwać treści które sami opublikowali, co także jest wyrazem zarządzania informacją, w tym przypadku w zakresie rozpowszechniania. Najczęściej rozmówcy usuwali stare zdjęcia, ponieważ z czasem stwierdzili, że nie wyglądają już na nich korzystnie lub są one nieaktualne. Dodatkowo przeglądają także swoje wcześniejsze aktywności, które z perspektywy czasu mają dla nich inne znaczenie:

(...) jak wróciłam do tego, np. jakie głupoty ja tam komentowałam, jak byłam młodsza, to pousuwałam albo poukrywałam. Wydawało mi się to żałosne. [Iwona]

Powyższe słowa są dobrym przykładem traktowania swojego profilu jako swojego wizerunku w Sieci. Iwona, podobnie jak pozostałe osoby, kontroluje wygląd swojego konta oraz treści, które się na nim pojawiają.

Rozmówcy zwracają także uwagę na treści, które są im wyświetlane na Facebooku. Ciekawą kwestią wyłaniającą się z przeprowadzonych wywiadów jest także sposób przyswajania informacji, które wyświetlają się użytkownikom. Część osób biorących udział w badaniu podkreśliła, że nie czyta wszystkich informacji, które widzi na swojej tablicy. Ograniczają się do pobieżnego przeglądania treści, klikając w te, które zainteresują ich na tyle, by przeczytać całą informację:

Zależy jakie są, bo na przykład załóżmy, że jakiś sklep opublikuje, że jest jakaś promocja, to przeczytam, bo do niego chodzę, ale generalnie nie wczytuję się we wszystkie informacje, jakie tam podają. [Patrycja]

Równocześnie rozmówcy wskazują na inną ważną kwestię dotyczącą treści na Facebooku:

Facebook jest dla mnie tak jak dla niektórych ludzi Onet czy Interia, że mam tam takie informacje, które akurat są aktualne i podchodzą pod moje zainteresowania. Więc można powiedzieć, że to takie moje źródło informacji na co dzień. [Michał]

Wypowiedź Michała jest bardzo istotna, ponieważ podkreśla on, że traktuje Facebooka jako podstawowe źródło informacji. Z uwagi na fakt, że wyświetlają się mu głównie informacje, które potencjalnie mogą go zainteresować, istnieje prawdopodobieństwo, że będzie widział informacje, które chce widzieć, a w efekcie coraz trudniej będzie mu się wydostać z bańki, w której się znajduje.

\subsection{Wiedza na temat personalizacji treści}

Kolejnym aspektem, który wyklarował się na podstawie wypowiedzi osób biorących udział w badaniu, jest stopień świadomości użytkowników na temat personalizacji treści. Interesujące było zwłaszcza to, czy użytkownicy zauważają przejawy personalizacji w internecie oraz jaki mają do tego stosunek. Ważne było także to, czy starają się zapobiegać jej negatywnym aspektom. W założeniu personalizacja 
pozwala dopasować treści docierające do użytkowników do ich upodobań oraz zainteresowań. Obecnie jest to bardzo powszechne zjawisko w Sieci, przejawiające się najczęściej poprzez wyniki wyszukiwań w przeglądarkach, a w największym stopniu poprzez reklamy.

Wypowiedzi badanych wskazują, że większość z nich umie wskazać przejawy personalizacji treści w internecie. Najczęściej badane osoby kojarzyły to z określonymi reklamami, które wyświetlają im oglądane wcześniej rzeczy w sklepach internetowych bądź powiązywane były z ich wyszukiwaniami:

No to jest właśnie to dopasowanie tych reklam pod użytkownika. Dotyczą tak jakby nas, to czego oczekujemy, szukamy, interesujemy się. [Patrycja]

Patrycja wskazuje na reklamy jako główny przejaw personalizacji. Wśród rozmówców występuje różnorodny stosunek do tego typu reklam. Niektóre osoby wskazały na ich przydatność, ponieważ pozwala to na dotarcie do ciekawych informacji, np. o promocjach w sklepach internetowych. Były także wypowiedzi, które wykazywały obojętny stosunek wobec personalizowanych reklam, z uwagi na wyświetlanie się rzeczy, które już wcześniej widzieli, wobec tego nie uznają ich za ciekawe. Niektórzy rozmówcy wskazali, że reklamy irytują ich, szczególnie gdy przez przypadek wejdą na niechcianą stronę i w efekcie wyświetla się im reklama niezwiązana $\mathrm{z}$ ich zainteresowaniami lub też zupełnie im przecząca. Na uwagę zasługują wypowiedzi osób, które podkreślają funkcję reklamy i przyznają, że spełnia ona swoje zadanie:

Czasami jak czegoś szukam długo i wbiję sobie do głowy, że to chcę mieć i potem jeszcze oglądam te reklamy, prześladuje mnie to na tym FB, to tym bardziej się to tak wzmaga, że chcę to kupić. [Iwona]

Wypowiedź Iwony świadczy o tym, że w jej przypadku wyświetlana reklama spełnia swoją funkcję. Wśród przeprowadzonych wywiadów pojawiła się także inna interesująca wypowiedź. Rozmówczyni podkreśla w niej, że personalizowane reklamy sprawiają, że czuje się inwigilowana w internecie:

No jest to takie już chyba wkraczanie w tą prywatność. To jest trochę przerażające w sumie nieraz. To, co przed chwilą robiłaś, wchodzisz na Facebooka i od razu to samo tam masz. To jakby tak mega połączone wszystko jest i to jest przerażające. Tak naprawdę wszystko wiedzą o tobie. [Natalia]

Natalia przejawia wyższą niż pozostali uczestnicy świadomość w kwestii naruszania prywatności w internecie, jednak jak sama twierdzi, nie potrafi się przed tym chronić. Kolejną osobą, która posiada wysoką wiedzę na temat funkcjonowania mechanizmów w internecie, jest Michał. Podobnie jak pozostali uczestnicy wskazał na powiązanie reklam z jego wcześniejszymi wyszukiwaniami, a dodatkowo wspomniał także o sposobach niwelowania ich nadmiernej ilości: 
No przed reklamami niby można się chronić tym adblockerem. Ale ja z tego nie korzystam, wiem, że tam tak jakby ogranicza, ale z tego co mi się wydaje, to nie każdą reklamę. Często na YouTubie, jak się puszcza jakiś filmik, to przed filmikiem jest reklama. A jak włączysz adblocka, to tej reklamy od razu nie ma. Na Facebooku nie wiem, ale chyba nie blokuje ten adblocker. To znaczy, nie mówię, że na YouTubie blokuje wszystko, bo tak nie jest, ale na pewno ogranicza. [Michał]

Równie ciekawą kwestią była wiedza przedstawicieli pokolenia $\mathrm{Z}$ na temat mechanizmów funkcjonujących w internecie. Na 13 osób biorących udział w badaniu właściwym tylko jedna powiązała pojęcie algorytmu z internetem. Pozostałe osoby nie znały tego mechanizmu lub kojarzyły go z innymi dziedzinami, takimi jak matematyka. Podobnie wygląda poziom wiedzy badanych gimnazjalistów na temat „ciasteczek” (cookies). Większość badanych osób potrafiła wskazać, że występują one na stronach internetowych, jednak nie potrafiła określić, co oznaczają. Jedna z badanych kojarzyła sposób ich funkcjonowania, natomiast nikt z grupy badanych nie usuwa ciasteczek - ograniczają się jedynie do zamykania komunikatu. Wiele osób wskazało także na irytujący stosunek do powiadomienia o „ciasteczkach” (cookies), gdyż często zasłania on treści na stronie, którą odwiedzają:

No wiem, że praktycznie każda strona $\mathrm{z}$ tego korzysta... Z informacji czy coś takiego... I to w sumie tyle. Nie interesowałam się jakoś bardziej, o co w tym chodzi, ale wiem, że właśnie te strony to mają. [Magda]

Należy jednak podkreślić, że osoby biorące udział w badaniu, pomimo nieznajomości pojęć takich jak personalizacja lub algorytm, potrafiły trafnie wskazać ich przejawy w Sieci. Dodatkowo, pomimo braku zaawansowanej wiedzy, badani zarządzają informacją $\mathrm{w}$ internecie. Ciekawym zagadnieniem są przyczyny braku wiedzy na temat mechanizmów funkcjonowania serwisów internetowych. Badani zwrócili uwagę na kwestię regulaminów, które mogłyby być źródłem takiej wiedzy, jednak rzadko kiedy są czytane przez internautów. Rozmówcy zaznaczali, że są one za długie, napisane skomplikowanym językiem oraz nieczytelne dla większości z nich:

To jest napisane ciężkim językiem, myślę, że dużo ludzi go nie rozumie. Wydaje mi się, że to taka specjalna zagrywka, żeby ludzie tego nie czytali i tyle. [Agnieszka]

Co ciekawe, jedna osoba doświadczyła konsekwencji w związku z kliknięciem zgody pod nieprzeczytanym regulaminem:

Tak. Musiałam zapłacić Pobieraczkowi 100 zł. Bo założyłyśmy sobie tam konto z moją siostrą. I na fałszywe dane. I okazało się, że niby na te 14 dni masz za darmo, a potem naliczają ci opłaty. No i się przestraszyłyśmy z moją siostrą i zapłaciłyśmy. [Iwona]

Jak przyznaje Iwona, wie, że powinna czytać regulaminy, i pomimo nieprzyjemności, jakie miała $z$ tego powodu, nadal tego nie robi, podobnie jak wszystkie osoby biorące udział w badaniu. 
Świadomość badanych osób dotycząca personalizacji treści w Sieci często jest fragmentaryczna, oparta na własnych spostrzeżeniach i intuicji, których nie powiązują w całość ze względu na brak pełnej wiedzy dotyczącej tego obszaru. Jednocześnie potrafią wskazać przejawy personalizacji w internecie, podając przykłady tego zjawiska. Poziom wiedzy osób biorących udział w badaniu jest zróżnicowany, część z nich posiada rozbudowaną wiedzę, a część nie zauważa wielu mechanizmów funkcjonujących w Sieci. Jest to uwarunkowane sposobem korzystania $\mathrm{z}$ internetu. Osoby, które przejawiają większą aktywność, na przykład poprzez prowadzenie własnego kanału, na którym publikują treści bądź zainteresowanie tym obszarem, dostrzegają więcej prawidłowości i zasad, które są obecne w internecie.

\section{Wnioski i podsumowanie}

Podsumowując tę część badania, należy wyodrębnić kilka głównych wątków dotyczących zarządzania informacją w internecie.

Badanie wykazało, że gimnazjaliści znajdują się w spersonalizowanych bańkach informacyjnych, a także potrafią wskazać przejawy tego zjawiska. W przeważającej części nie są natomiast w pełni świadomi zasad działania mechanizmów filtrujących. $Z$ uwagi na występowanie bańki oraz także wyspecjalizowanej personalizacji treści, istnieje prawdopodobieństwo, że użytkownicy mogą nie mieć dostępu do zróżnicowanych informacji, oddających np. odmienny punkt widzenia.

Badanie potwierdza tezę, że przestrzeń platform komunikacyjnych takich jak Facebook jest dla pokolenia $\mathrm{Z}$ naturalnym środowiskiem zarządzania informacją, a narzędzia social media są chętnie wybieranymi, a często jedynymi narzędziami służącymi do tych celów.

Większość osób biorąca udział w badaniu w pewnym stopniu świadomie zarządza informacją w internecie. Zazwyczaj użytkownicy dodają bądź usuwają treści ze stron, które już nie są dla nich interesujące. Równocześnie sami tworzą i rozpowszechniają informacje, takie jak zdjęcia czy aktywności w postaci postów, niektórzy prowadzą własne kanały, np. w ramach YouTube.

Badani są świadomi zagrożeń i różnego rodzaju naruszeń (np. prywatności) ze strony firm dostarczających usługi informacyjno-komunikacyjne, jednak nie wiedzą, w jaki sposób mogą się przed tym chronić, a nawet jeśli wiedzą, to raczej nie podejmują działań, nie czytają także regulaminów usług, uznając je za niezrozumiałe.

Użytkownicy czują potrzebę właściwego zarządzania informacją prywatną, w postaci np. dobrej prezentacji swojej osoby w internecie, a dbanie o wygląd swojego konta w serwisie społecznościowym jest tego przykładem. Bardzo istotną kwestią, która powinna zwrócić uwagę, jest traktowanie Facebooka jako podstawowego źródła informacji przez użytkowników.

Badanie pokazało, że uznawani za cyfrowych tubylców gimnazjaliści mają ograniczoną wiedzę na temat różnych mechanizmów działających w przestrzeni 
internetu. Mimo że technologie informacyjno-komunikacyjne towarzyszą im na co dzień i są integralnym elementem ich życia, często stanowią dla nich wyzwanie. Zagadnienia związane $\mathrm{z}$ funkcjonowaniem algorytmów są na tyle skomplikowane, że młodzież, nawet jeśli ma świadomość ich istnienia, to nie do końca rozumie poszczególne mechanizmy. Biorąc pod uwagę złożoność problemu, należałoby przeprowadzić dalsze badania jakościowe w celu ustalenia przyczyn takiego stanu rzeczy, a także badania ilościowe w celu zdiagnozowania, jaki jest stopień zróżnicowania wiedzy i kompetencji wśród młodzieży w tym zakresie i czym to zróżnicowanie jest uwarunkowane.

\section{Bibliografia}

Bard A., Soderqvist J., Netokracja. Nowa elita władzy i życie po kapitalizmie, tłum. P. Cypryański, Wydawnictwa Akademickie i Profesjonalne, Warszawa 2006.

Bauman Z., Lyon D., Płynna inwigilacja. Rozmowy, Wydawnictwo Literackie, Kraków 2013.

Christakis N.A., Fowler J.H., W sieci. Jak sieci społeczne kształtuja nasze życie, Smak Słowa, Sopot 2011.

Iwasiński Ł., Przyczynek do rozważań nad suwerennością konsumenta w epoce danetyzacji i Big Data, „Kultura - Historia - Globalizacja” 2017, nr 21, s. 119-133.

Jones W., Keeping Found Things Found, New York 2008.

Jones W., Personal Information Management, „Annual Review of Information Science and Technology" 2007, vol. 41, no. 1, s. 453-504.

Kreft J., Za fasada społeczności, Wydawnictwo Uniwersytetu Jagiellońskiego, Kraków 2015.

Lechowicz N., Pikuła D., Determinanty kształtujące nowe pokolenia oraz ich implikacje dla wspótczesnego świata, „Rynek, Społeczeństwo, Kultura” 2013, nr 3(7), s. 17-23.

Malinowski B., Jak Facebook zamyka nas w bańce informacyjnej. Algorytm filtrujacy newsfeed a zjawisko filter bubble, „Zarządzanie Mediami” 2006, t. 4(1), s. 15-22.

Nguyen T.T., Hui P.M., Harper M., Terveen L.G., Konstan J.A., Exploring the Filter Bubble: The Effect of Using Recommender Systems on Content Diversity, [w:] WWW 2014 - Proceedings of the 23rd International Conference on World Wide Web, s. 677-686.

Niedźwiedziński M., Klepacz H., Szymańska K., Budowanie marki osobistej w mediach społecznościowych, „Marketing i Zarządzanie” 2018, nr 5(48), s. 339-349.

Nowina-Konopka M., Infomorfoza. Zarządzanie informacja w nowych mediach, Wydawnictwo Uniwersytetu Jagiellońskiego, Kraków 2017.

Pariser E., The Filter Bubble: What the Internet Is Hiding From You, London 2011.

Popiołek M., Czy można żyć bez Facebooka? Rola serwisów społecznościowych w sieciowym społeczeństwie informacyjnym, Wydawnictwo Uniwersytetu Jagiellońskiego, Kraków 2018.

Prensky M., Digital Natives, Digital Immigrants, „On the Horizon” 2001, vol. 9, nr 5.

Ptaszek G., Edukacja medialna 3.0. Krytyczne rozumienie mediów cyfrowych $w$ dobie Big Data i algorytmizacji, Wydawnictwo Uniwersytetu Jagiellońskiego, Kraków 2019.

Stunża G.D., Wyzwania kultury i edukacji uczestnictwa. Pokolenie Z i pokolenie Alfa, Edukator Medialny, Gdańsk 2018.

Szpunar M., Koncepcja bańki filtrującej a hipernarcyzm nowych mediów, „Zeszyty Prasoznawcze" 2018, t. 61, nr 2(234), s. 191-200. 